K. A. Sabirov, T. T. Shakirov, and M.-R. I. Shamsutdinov

Khimiya Prirodnykh Soedinenii, Vo1. 2, No. 6, p. 443, 1966

Cytisine [1] is produced from the seeds of the plant Thermopsis lanceolata R. Br. [2]. The epigeal part of Thermopsis alterniflora Rgl, contains about $3 \%$ of total alkaloids [3]. This plant is widely distributed in Central Asia [4] and is more economically promising than $T$. lanceolata. We have established that by treating the epigeal part of $T$. alterniflora the technological cycle is greatly simplified. Consequently, it is appropriate to organize the production of cytisine from the epigeal part of $T$. alterniflora.

The plant collected in the budding period was ground and extracted by percolation. Organic solvents, water, and aqueous solutions of acids of various concentrations at various temperatures were used as extractants. On extraction with chloroform, the yield of cytisine was $1.2 \%$ and that of pachycarpine $0.25 \%$ of the weight of the raw material.

In the subsequent experiments, pure water, water containing $0.01 \%$ of the surfactant "Tween-80", $0.5 \%$ and $1 \%$ aqueous solutions of hydrochloric acid, and $1 \%$ and $3 \%$ solutions of sulfuric acid were used as extractants. The alkaloids from the extracts were adsorbed on $\mathrm{KU}-1$ and $\mathrm{KU}-2$ ion exchangers. They were desorbed with $90 \%$ alcohol containing $1.5 \%$ of ammonia.

The best results were obtained by extraction with $1 \%$ aqueous hydrochloric acid and $2 \%$ aqueous sulfuric acid at $55^{\circ} \mathrm{C}$ with adsorption on KU-1 cation exchanger in the hydrogen form, which gave a yield of cytisine of $1.0 \%$ and of pachycarpine of $0.2 \%$, respectively, on the weight of the raw material.

The experiments carried out show that the most useful method for the industrial production of cytisine from T. alterniflora is extraction with $1 \%$ aqueous hydrochloric acid or $2 \%$ aqueous sulfuric acid at $50-60^{\circ} \mathrm{C}$ with subsequent adsorption on $\mathrm{KU}-1$ cation exchanger.

The industrial method for the production of cytisine is being developed further.

\title{
REFERENCES
}

1. M. D. Mashkovskii, Medicinal Substances [in Russian], Moscow, 110, 1960.

2. M. V. Tsarev, DAN SSSR, 42, 127, 1944.

3. Z. P. Pakudina and S. Yu. Yunusov, Izv. AN UzSSR, Ser. khim. nauk, no. 2, 69, 1957.

4. Flora of the USSR [in Russian], Moscow, 9, 41, 1945.

21 June 1966

Institute of the Chemistry of Plant Substances, AS UzSSR

\section{STRUCTURE OF ROBUSTININE}

I. M. Saitbaeva, G. P. Sidyakin, and S. Yu. Yunusov

Khimiya Prirodnykh Soedinenii, Vol. 2, No. 6, pp. 443-444, 1966

Continuing the separation of the total alkaloids of the roots of Haplophyllum robustum Bge. (family Rutaceae) [1], we have isolated a crystalline base with $\mathrm{mp} 232^{\circ}-233^{\circ} \mathrm{C}$ having the composition $\mathrm{C}_{11} \mathrm{H}_{11} \mathrm{O}_{3} \mathrm{~N}$ and the analytical formula $\mathrm{C}_{9} \mathrm{H}_{5} \mathrm{ON}\left(\mathrm{OCH}_{3}\right)_{2}$.

Chromatography of the alkaloids on a thin fixed layer of alumina in the butan-1-ol-pyridine-acetic acid-water (45:30:9:6) system gave a single spot with a $R_{f}$ value of 0.60 . We have called the alkaloid robustinine (I). This compound is optically inactive and readily soluble in organic solvents.

The UV spectrum (in alcohol) is very similar to that of derivatives of quinol-2-one (maxima at 270 and $282 \mathrm{~m} \mu$ ). [2]. The IR spectrum of robustinine has a strong absorption band with a maximum at $1630 \mathrm{~cm}^{-1}$ showing the presence of a $-\mathrm{NH}-\mathrm{CO}-$ group [3].

When robustinine was heated with alcoholic hydrochloric acid, the methoxy group in the $\gamma$ position was saponified with the formation of norrobustinine with $\mathrm{mp} 245^{\circ}-246^{\circ} \mathrm{C}$ (II). This gave a nitroso derivative with $\mathrm{mp} 226^{\circ}-227^{\circ} \mathrm{C}$ (III). 